\title{
Short Communication: Comparing the growth of stem explants between Citrus reticulata var. Tawangmangu and $C$. reticulata var. Garut using in vitro culture methods
}

\author{
ERMA PRIHASTANTI", ENDAH D. HASTUTI, SRI WIDODO AGUNG SUEDY \\ Structure and Function of Plant Laboratory, Department of Biology, Faculty of Science and Mathematics, Universitas Diponegoro. \\ Jl. Prof. Soedarto, Tembalang, Semarang 50275, Central Java, Indonesia. Tel.: +62-24-7460041, Fax.: +62-24-7460033, "email: eprihast@ yahoo.co.id
}

Manuscript received: 16 May 2020. Revision accepted: 28 November 2020.

\begin{abstract}
Prihastanti E, Hastuti ED, Suedy SWA. 2020. Short Communication: Comparing the growth of stem explants between Citrus reticulata var. Tawangmangu and C. reticulata var. Garut using in vitro culture methods. Biodiversitas 21: 5845-5849. Several efforts have been made to preserve Citrus reticulata var. Tawangmangu and Citrus reticulata var. Garut as indigenous Indonesian mandarin cultivars, including in vitro tissue culture methods. This study aimed to determine growth differences of the stem explants of $C$. reticulata var. Tawangmangu and C. reticulata var. Garut,which planted on the same Murashige and Skoog (MS) media. The treatment groups were derived from different explants, grown in 4 separate culture bottles for 35 days at $25^{\circ} \mathrm{C}$. The observed parameters included the percentage of explants indicating callus development browned-colored explants, and the contaminated explants. Among $C$. reticulata var. Tawangmangu explants, $23.53 \%$ indicated callus development, $29.42 \%$ were browned-colored explants, and $0 \%$ indicated contamination. In contrast, among the C. reticulata var. Garut explants, $0 \%$ indicated callus development, $7.14 \%$ browncolored, and $7.14 \%$ indicated contamination. The stems explants from $C$. reticulata var. Tawangmangu showed a tendency to develop calluses, but the explants of $C$. reticulata var. Garut was able to support the growth of shoots. C. reticulata var. Tawangmangu and Garut mandarin stem explants showed differences of shoot growth because physiological conditions varied according to the variety.
\end{abstract}

Keywords: Citrus reticulata var. Tawangmangu, Citrus reticulata var. Garut, callus growth, stem explants

\section{INTRODUCTION}

The local Indonesian mandarin cultivars, Citrus reticulata var. Tawangmangu and Citrus reticulata var. Garut, have become among the most popular horticultural commodities and most desired fruits from the Karanganyar Regency (Ibad 2009); however, its availability is insufficient to fulfill high demands due to the low productivity. Recently, farmers have struggled to cultivate and maintaining stronger and healthier mandarin trees that are capable of producing large numbers of mandarins within short periods of time.

Citrus greening disease (CGD) is a disease that attacks mandarin plants and has become a serious threat to mandarin production in every country (Batool et al. 2007). Citrus Vein Phloem Degeneration (CVPD) disease is a major cause of low productivity among mandarin plants (Yuniti et al. 2017). Decaying stems can also become obstacles to efforts to increase the citrus productivity during pre-and post-harvest periods, causing spots around stem area to become firm and dry, while the fruit skin softens and rots (Kaur et al. 2007).

To address these problems, there were conservation efforts made to recover $C$. reticulata var. Tawangmangu and $C$. reticulata var. Garut, these were aimed to preserve and maintain the highest quality products. According to Smith (2012), tissue culture methods can be used to propagate plants under in vitro conditions. In vitro propagation can result in the rapid multiplication of plants in relatively short periods of time (Jha and Ghosh 2005; Purohit 2012). Moreover, this method can produce highquality plants with favorable genetics that are disease-free (Suman 2017). In general, in vitro culture methods have been used to multiply plants; however, this technology can also be used to facilitate plant reproduction and recovery, eliminate diseases, and induce the production of secondary metabolites in plants (Hussain et al. 2012).

The plant material that used to begin in vitro cultures is crucial to determine the success of the culture process. Other factors that can affect the responses of explant tissue cultures include: genotype, the physiological status of the donor plant, and the position, source, age, size, and density of the explant (Yildiz 2012). Mandarin branch explants can be used during in vitro cultures. Planting different varieties of explants, derived from citrus branch edges, under the same growth media conditions allows the evaluation of various growth processes and physiological responses. According to Delporte et al. (2014), plant regeneration from tissue cultures depends on genetics, and factors, including age, differentiation degree, and physiological responses, can affect an explant's responses to different culture conditions. Plant regeneration in culture occurs through embryogenesis or organogenesis. Branch explants from different varieties of citrus have different physiological responses to culture media. This study aimed to determine differences in the growth of stem explants, derived from $C$. reticulata var. Tawangmangu and $C$. 
reticulata var. Garut, planted in the same Murashige and Skoog (MS) media.

\section{MATERIALS AND METHODS}

\section{Research material}

The materials used in this study included stem explants from $C$. reticulata var. Tawangmangu (JKT) and $C$. reticulata var. Garut (JKG), $\mathrm{dH}_{2} \mathrm{O}$, methylated spirit, selfmade MS media, $0.1 \mathrm{~g} / \mathrm{L}$ Myo-inositol, $9.5 \mathrm{~g} / \mathrm{L}$ jelly from agar, $30 \mathrm{~g} / \mathrm{L}$ sucrose, hydrochloric acid $(\mathrm{HCl})$, sodium hydroxide $(\mathrm{NaOH}), 70 \%$ alcohol, $96 \%$ alcohol, detergent (Mamalime, Indonesia), $100 \mathrm{~mL} / \mathrm{L}$ clorox, $100 \mathrm{mg} / \mathrm{mL}$ Antracol fungicide (Bayer, Germany), and $10 \mathrm{mg} / \mathrm{L}$ Phenoxymethyl penicillin antibiotics (Pharos, Indonesia).

\section{Media preparation}

MS media was prepared by heating $\mathrm{dH}_{2} \mathrm{O}$ in a beaker over a hotplate, added by $4.43 \mathrm{~g} / \mathrm{L} \mathrm{MS}$, and homogenized. Then, $0.1 \mathrm{~g} / \mathrm{L}$ Myo-inositol and $30 \mathrm{~g} / \mathrm{L}$ sucrose were added. After the solution was homogenous, added $9.5 \mathrm{~g} / \mathrm{L}$ jelly was added and homogenized. One liter of $\mathrm{dH}_{2} \mathrm{O}$ was added to the solution, and $\mathrm{pH}$ was adjusted to 5.6-5.8, using a $\mathrm{pH}$ meter either $\mathrm{HCl}$ or $\mathrm{NaOH}$, as necessary. Prepared media was poured into cultural bottles and sterilized, for 15-20 minutes at $121^{\circ} \mathrm{C}$. After sterilization, the media was stored in a cultural laboratory for 3 days to ensure no contaminants were present.

\section{Explant sterilization and culture}

This study used organogenesis in vitro culture using the JKT and JKG young stems as an explant without any hormone addition. JKT and JKG stem explants were cut on the edge (apex). Explants were soaked in an anti-bacterial detergent, and the leaves and stems were separated to facilitate the cleaning process. Explants were rinsed with Clorox under running water to eliminate detergent residue. Next, explants were placed in $\mathrm{dH}_{2} \mathrm{O}$ for sterilization, prior to being placed in a laminar flow cabinet.

Explants were sterilized in a laminar flow cabinet using a temperature of $121^{\circ} \mathrm{C}$. First, explants were sterilized in a solution containing $0.01 \mathrm{~g}$ antibiotics in $100 \mathrm{~mL} \mathrm{dH}_{2} \mathrm{O}$, for 20 minutes. Next, explants were soaked in a solution containing $0.1 \mathrm{~g}$ fungicide in $100 \mathrm{~mL} \mathrm{dH} \mathrm{d}_{2} \mathrm{O}$, for 20 minutes. Explants were rinsed with $10 \mathrm{~mL}$ Clorox in 100

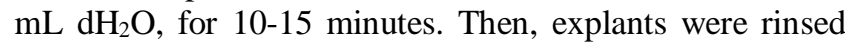
with $\mathrm{dH}_{2} \mathrm{O}$, followed by a rinse with $25 \mathrm{~mL} 96 \%$ alcohol in

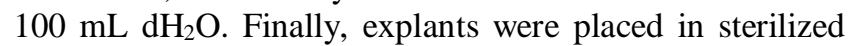
$\mathrm{dH}_{2} \mathrm{O}$ until ready to be moved on the culture media. Each of 4 culture bottles with 4 explants per bottle $(n=16)$, representing 4 replicates, and incubated for 35 days at $25^{\circ} \mathrm{C}$ and room humidity $70 \%$. The explants were exposed with a TL 40 watt with dark and light periods longed for 11 and 13 hours, respectively.

\section{Data analysis}

The following parameters were observed: the percentage of explants showing callus development, the percentage of brown-colored explants, and the percentage of explants showing signs of contamination. Average shoot growth and the numbers of surviving explants were analyzed using the Student's t-test.

The percentage of explants showing callus development (\%) was calculated using the following formula:

Number of explants with callus development

The total number of planted explants x 100\%

The percentage of brown-colored explants (\%) was calculated using the following formula:

Total of brown-colored explants

Total number of planted explants x $100 \%$

The percentage of explants showing contamination (\%) was calculated using the following formula:

Total of contaminated explants

Total number of planted explants x 100\%

The 2 citrus varieties were the independent variables, while the average shoot growth and the surviving number of explants were the dependent variables.

\section{RESULTS AND DISCUSSION}

The percentage of explants showing callus development

The results showed differences in explant growth based on the percentage of explants with callus formation. Among the JKT explants, $23.53 \%$ showed callus formation, contrary, none of the JKG explants $(0.00 \%)$ showed callus formation (Table 1; Figure 1).

The callus growth within a plant species depends on the type of starting material (juvenile or old), the physiology of the plant, and the growth conditions (Bhatia et al. 2015). The physiological status of each plant varies because plants grow at different rates under different conditions and during different seasons. Different growth responses are affected by both endogenous and exogenous levels of zinc pyrithione (ZPT), a chemical that controls the growth rate. The JKT and JKG explants represent different varieties that express different biochemical compounds, including the primary and secondary metabolites that affect callus formation during somatic embryogenesis.

According to Jariteh et al. (2015), different genotypes within a plant species have differing embryogenesis capabilities, depending on genetic and biochemical properties, the levels of key elements in the regeneration pathway, and the metabolism of endogenous phytohormones. Callus formation is determined by the modulation of plant hormone signaling, especially the auxin and cytokine pathways (Ikeuchi et al. 2013). The combination of cytokine and auxin hormones in explants can promote organogenesis and induce the development of calluses (Aguirre-Alberto and Martinez-Cardenas 2018). A primary factor that determines the browning process during in vitro cultures is the presence of a wound, caused by cutting the tissue. 
Table 1. The percentages of Tawangmangu and Garut mandarin explants with callus formation, browning, and signs of contamination

\begin{tabular}{cccccccc}
\hline \multirow{2}{*}{ Variant } & $\begin{array}{c}\text { Total } \\
\text { planted } \\
\text { explants }\end{array}$ & $\begin{array}{c}\text { Total explants } \\
\text { with callus }\end{array}$ & $\begin{array}{c}\text { Callus } \\
(\boldsymbol{\%})\end{array}$ & $\begin{array}{c}\boldsymbol{\Sigma} \text { Brown-colored } \\
\text { explants }\end{array}$ & $\begin{array}{c}\text { Browning } \\
(\boldsymbol{\%})\end{array}$ & $\begin{array}{c}\text { Contaminated } \\
\text { explants }\end{array}$ & $\begin{array}{c}\text { Contamination } \\
(\boldsymbol{\%})\end{array}$ \\
\hline JKT & 17 & 4 & $23.53 \%$ & 5 & $29.42 \%$ & 0 & $0.00 \%$ \\
JKG & 14 & 0 & $0.00 \%$ & 1 & $7.14 \%$ & 1 & $7.14 \%$ \\
\hline
\end{tabular}

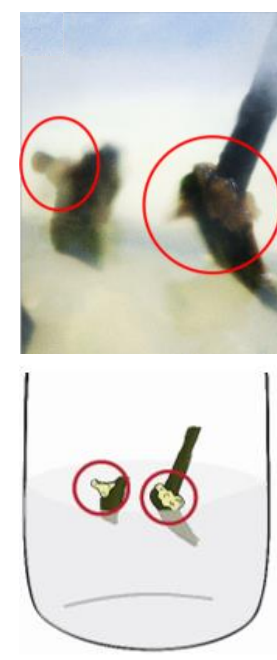

$\mathbf{A}$
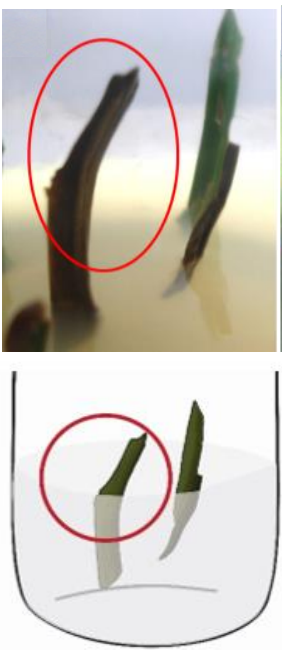

B
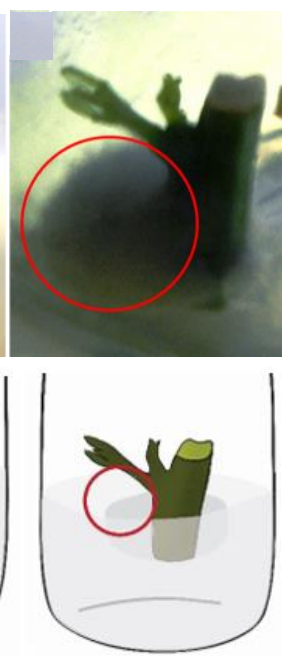

C
Figure 1. The morphologies of Tawangmangu and Garut mandarin stem explants (above) and its schematic illustrations (below). A. Tawangmangu mandarin stem explants with callus formation. B. Browning stem explants from Tawangmangu mandarin. C. The contaminated stems from Garut mandarin

\section{The percentage of brown-colored explants}

Contamination was only found in $7.14 \%$ of $\mathrm{JKG}$ explants (Table 1; Figure 1). Browning is influenced by the presence of phenolic compounds in all parts of the explant. High percentages of brown-colored explants indicate the presence of high concentrations of phenolic compounds, which prevent explant growth. According to Corduk and Aki (2011) and Singh (2018), a brown-colored explant is a serious problem during micropropagation stages which is associated with the oxidation of phenolic compounds. The addition of activated charcoal has been described as an effective treatment for overcoming phenolic exudation (Chinnappan 2011). Tang and Newton (2004) reported that browning tissue can be induced to regenerate by using the in vitro method culturing method to induce callus formation in some woody plants, indicating plant regeneration through organogenesis.

The browning observed in stem explants from JKT and JKG indicates the deterioration of the explant physiology. The browning process is a natural phenomenon, representing an adaptive mechanism in plants in response to other physical effects, such as peeling and cutting. According to Tabiyeh et al. (2006), phenylalanine ammonia-lyase is an enzyme associated with phenyl propanol, which plays a role in the browning process.

\section{The percentage of contaminated explants}

The source of contamination among explants is generally from the explant itself or the in vitro culturing process. According to Cassells (2012), the microbial contamination, mostly bacterial, of plant tissue cultures is due to the high levels of nutrition available in MS media. The contamination is caused by both exogenous and endogenous microbes (Leelavathy and Sankar 2016). Ray and Ali (2017) suggested that contamination can be caused by the explants themselves. Most contaminants can be treated by maintaining aseptic conditions. Surface microbe contaminants, such as epiphytes, can be treated by sterilizing the surface. In contrast, endophytic contaminants (inside explants) are uncontrollable, small organisms that can enter the media, and invade unsterilized equipment and dirty environments. Therefore, the environment, equipment, media, and plant materials must be sterilized prior to in vitro culture. The part of the plant used to derive explants can also affect contamination levels.

In this study, the use of citrus leaf branches as explants facilitates direct contact between contaminants and explant tissue cells which increases the opportunities for contamination. In accordance with Widiastuti et al. (2018), the explant's morphological surface and the presence of hairy or unsegmented explants can directly affect the level of contamination. Hairy explants require specific sterilization methods, such as Tween 20 solution, allowing the sterilization process to have direct contact with the explant's surface. The following pictures show the developments that lead to callus formation, browning, and contamination.

\section{Comparisons between average numbers of growing shoots and average numbers of surviving shoots}

Significant differences in growth were observed between JKT and JKG stem explants (Table 2, p < 0.05). The average number of shoots is closely associated with the ability of the explants to adapt to the in vitro conditions and the physiological status of the explants.

Based on Delporte et al. (2014), plant regeneration during tissue culture can be controlled genetically. Some factors, such as age, differentiation level, and physiological conditions, affect the responses of explants towards the culture conditions. Plant regeneration probably caused by embryogenesis or organogenesis. According to research performed by Leng et al. (2009), the primary obstacle to tissue culture is the browning of explants, forming a poisonous quinone compound. Browning is assumed to represent an oxidation process, involving phenol, PPO, and antioxidant enzymes. 

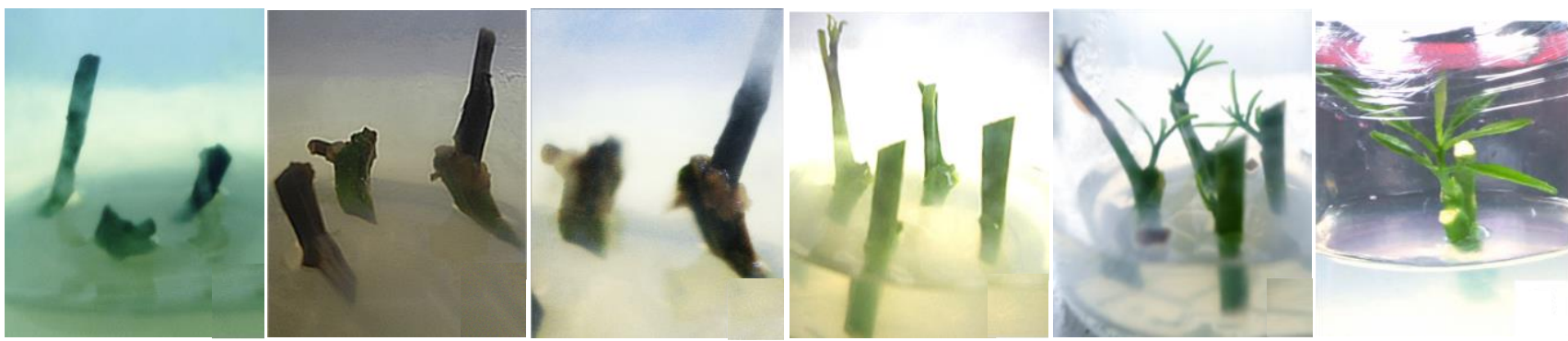

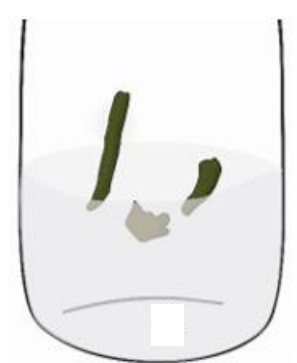

A

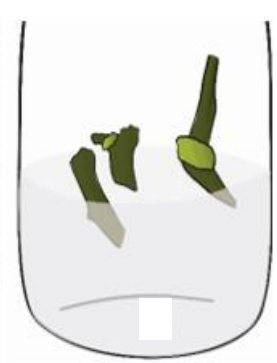

B

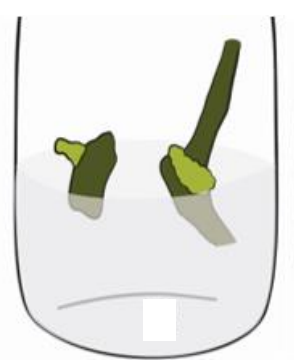

C

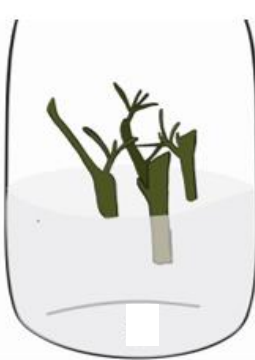

D

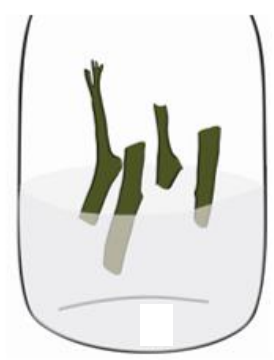

$\mathbf{E}$

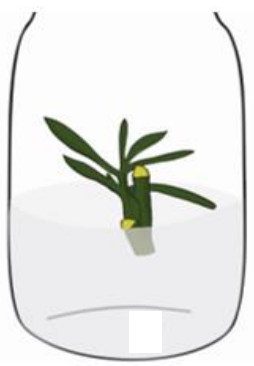

F

Figure 3. The morphology of Tawangmangu and Garut mandarin stems explants (above) and its schematic illustrations (below). A. Tawangmangu mandarin stems explants during the early cultivation period. B. Tawangmangu mandarin stems explants on day 24 . C. Tawangmangu mandarin stems explants at the end of the observation period. D. Garut mandarin stems explants during the early cultivation period. E. Garut mandarin stems explants on day 24. F. Garut mandarin stems explants at the end of the observation period.

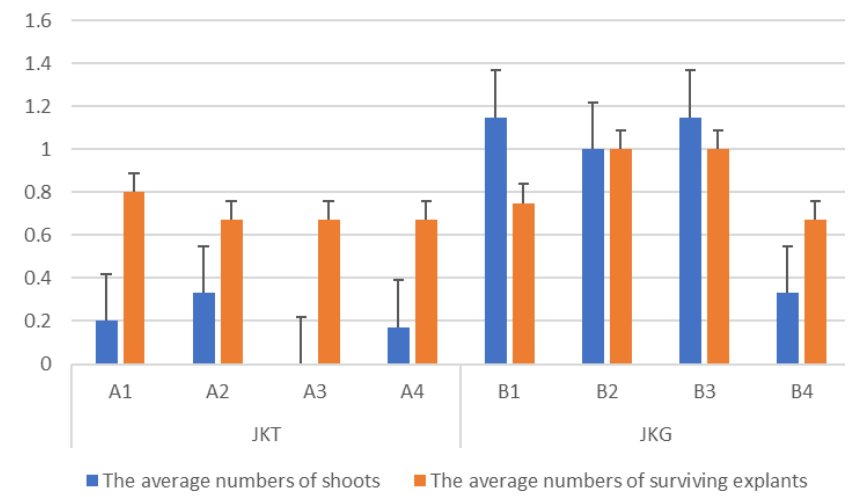

Figure 2. The average numbers of the shoots and surviving explants for JKT and JKG

Phenolic production during browning process could eventually lead to undeveloped explants, preventing in vitro regeneration. An experiment examined the overnight pre-treatment of Faba seeds with 1,000 mg/L polyvinylpyrrolidone (PVP) overnight, followed by cultivation with many types of explants, grown on tissue culture media containing an adsorbent (active charcoal) and an antioxidant (ascorbic acid, cysteine, and silver nitrate). The results showed that overnight treatment using PVT solution $(1,000 \mathrm{mg} / \mathrm{L})$ after unpeel the seeds, followed by cultivation culturing on MS media, containing $3 \%(\mathrm{~b} / \mathrm{v})$ sucrose, $0.8 \%(\mathrm{~b} / \mathrm{v})$ jelly, $2 \mathrm{mg} / \mathrm{L}$ BAP and $2 \mathrm{mg} / \mathrm{L}$ thidiazuron, and either ascorbic acid $(1 \mathrm{mg} / \mathrm{L})$ or active charcoal $(10 \mathrm{~g} / \mathrm{L})$, reduced the level of browning and increased shoot regeneration (Abdelwahd et al. 2008).

Unlike the number of growing shoots, the average number of surviving explants was not affected by the citrus variety that explants were derived from, and no significant difference was observed for the cultivation success rate (2 tailed Student's t-test, $\mathrm{p}>0.146$ ). The explants capable of growing are no brown-colored explants and free for contamination, indicating explants could adapt to the physiological conditions of the in vitro environment. The ability was likely affected by the internal and external conditions of the explants. According to Smith (2012), the ability is affected by five primary factors: the plant genotype, the physiological status of the explant source, the quality of explant, the explant size and location, and the season during which the explant was obtained. Explant origins can influence the growth and morphogenetic potential of the explant. Differences in regeneration capacities have been identified among explants from one organ variety. The size of the explants can also affect the numbers of shoots, as smaller explants require more time for shoot initiation (Harahap et al. 2014).

The growth of explants from JKT and JKG stems were compared starting on day 24 (early cultivation) through the end of the experiment (day 35, Figure 2). Some shoots, but no callus formations, were observed on the JKT stem explants. At the end of the experiment, the JKG explants were moved to new sterile media because the initial culture bottle was no longer sufficient for the growing explants, and the explants required increased nutrient availability because the new shoots began to grow leaves.

Citrus reticulata var. Tawangmangu and Garut mandarin stem explants on MS media showed differences in shoot growth because physiological conditions were varied according to the variety. Therefore, understanding the differences in the responses between the two varieties of explants would facilitate the determination of the 
effective propagation techniques necessary to obtain good quality seeds.

\section{ACKNOWLEDGEMENTS}

This research was financially supported by the Grand Research of Faculty of Science and Mathematics, Diponegoro University, Semarang, Indonesia.

\section{REFERENCES}

Abdelwahd R, Hakam N, Labhilili M, Udupa SM. 2008. Use of an adsorbent and antioxidants to reduce the effects of leached phenolics in vitro planlet regeneration of faba bean. Afr J Biotechnol 7 (8): 997 1002 .

Bhatia S, Sharma K, Dahiya R, Bera T. 2015. Modern Applications of Plant Biotechnology in Pharmaceutical Sciences. Academic Press, London.

Batool A, Iftikhar Y, Mughal S.M, Khan MM, Jaskani MJ, Abbas M, Khan IA. 2007. Citrus greening disease - a major cause of citrus decline in the world- a review. Hort Sci (Prague) 34 (4): 159-166. DOI:10.17221/1897-HORTSCI.

Cassells AC. 2012. Pathogen and biological contamination management in plant tissue culture: Phytopathogens, vitro pathogens, and vitro pests. Methods Mol Biol 877: 57-80. DOI: 10.1007/978-1-61779818-4_6.

Chinnappan RS, Ruthar N, Sethu SS. 2011. Rapid in vitro propagation of Premna serratifolia, a medicinally important declining shrub, India. Conserv Evid 8: 66-73.

Corduk N, Aki C. 2011. Inhibition of browning problem during micropropagation of Slideritis trojana Bornm, an endemic medicinal herb of Turkey. Romanian Biotechnol Lett 16 (6): 6760-6765.

Delporte F, Pretova A, Du Jardin P, Watillon B. 2014. Morpho-histology ang genotype dependence of in vitro morphogenesis in mature embryo cultures of wheat. Protoplasma 251 (6): 1455-1470. DOI: 10.1007/s00709-014-0647-7.

Hussain A, Iqbal AQ, Hummera N, Ikram U. 2012. Plant tissue culture: Current status and opportunities. IntechOpen. DOI: 10.5772/50568.

Harahap F, Poerwanto R, Suharsono, Suriani C, Rahayu S. 2014. In vitro growth and rooting of mangosteen (Garcinia mangostana L.) on medium with different concentrations of plant growth regulator. J Biosci 21 (4): 151-158. DOI:10.4308/hjb.21.4.151.

Ikeuchi M, Sugimoto K, Iwase A. 2013. Plant callus: Mechanisms of induction and repression. Plant Cell 25 (9): 3159-3173. DOI:10.1105/tpc.113.116053.
Jariteh M, Ebrahimzadeh H, Niknam V, Mirmasoumi M, Vahdati K. 2015. Developmental changes of protein, proline and some antioxidant enzyme activities in somatic and zygotic embryos of Persian walnut (Juglans regia L.). Plant Cell Tiss Organ Cult 122 (1): 101-115. DOI:10.1007/s1 1240-015-0753-z

Jha TB, Ghosh B. 2005. Plant Tissue Culture: Basic and Applied. Universities Press, India.

Kaur R, Rewal HS, Sethi A. 2007. Pre-harvest stem-end rot in citrus cultivars due to Colletotrichum gloeosporioides. Eur J Hortic Sci 72 (1): 20-25.

Leelavathy S, Sankar PD. 2016. Curbing the menace of contamination in plant tissue culture. J Pure Appl Microbiol 10 (3): 2145-2152.

Aguirre-Alberto L, Martinez-Cardenas M de L. 2018. Production of callus and roots from lateral meristems of Loeselia mexicana. Botanic Sci 96 (3): 405-414. DOI:10.17129/botsci.1910

Leng P, Su S, Wei F, Yu F, Duan Y. 2009. Correlation between browning, total phenolic content, polyphenol oxidase, and several antioxidation enzymes during pistachio tissue culture. Acta Horticulturae 829: 127132. DOI: 10.17660/ActaHortic.2009.829.17.

Purohit SD. 2012. Introduction to Plant Cell Tissue and Organ Culture. PHI Learning Pvt. Ltd., New Delhi.

Ray SS, Ali N. 2017. Biotic contamination and possible ways of sterilization: A review with reference to bamboo micropropagation. Braz Arch Biol Technol 60: e16160485. DOI:10.1590/1678-43242016160485

Singh CR. 2018. Review on problems and its remedy in plant tissue culture. Asian J Biol Sci 11: 165-172. DOI: 10.3923/ajbs.2018.165.172

Smith RH. 2012. Plant tissue culture: Techniques and Experiments. Academic Press, London.

Suman S. 2017. Plant tissue culture: A promising tool of quality material production with special reference to micropropagation of banana. Biochem Cell Arch 17 (1): 1-26.

Tang W, Newton RJ. 2004. Increase of polyphenol oxidase and decrease of polyamines correlate with tissue browning in Virginia pine (Pinus virginiana Mill.). Plant Sci 167 (3): 621-628. DOI: 10.1016/j.plantsci.2004.05.024

Tabiyeh DT, Bernard F, Shacker H. 2006. Investigation of glutathione, salicylic acid and GA3 effects on browning in Pistacia vera shoot tips culture. ISHS Acta Hort 726: 201-204.

Widiastuti Y, Bariyyah K, Istianingrum P, Restanto DP, Hartatik S. 2018. In vitro sterilization method of the Banyuwangi's local red durian leaf explants to several combination types of sterilization materials. Intl $\mathbf{J}$ Agric Environ Biores 3 (5): 262-273.

Yildiz M. 2012. The prerequisite of success in plant tissue culture: Highfrequency shoot regeneration. In: Leva A, Rinaldi LMR (eds.). Recent Advances in Plant In vitro Culture. IntechOpen, UK.

Yuniti IGAD, Wirawan IGP, Wijaya IN, Sritamin M. 2017. CVPDr DNA fragment affects differences in resistance to citrus vein phloem degeneration (CVPD) disease, nutrient deficiencies, and quality of fruits. Intl J Biosci Biotechnol 5 (1): 60-67. 